\title{
Aksi Game Berbasis Brain Computer Interface dengan Spektral Daya dan Learning Vector Quantization
}

\author{
Aditya Setiawan Putra*, Esmeralda C. Djamal, Rezki Yuniarti \\ Jurusan Informatika Fakultas MIPA \\ Universitas Jenderal Achmad Yani \\ Jl. Terusan Sudirman, Cimahi \\ *dithsetiawan@gmail.com
}

\begin{abstract}
Abstrak - Dalam video game dibutuhkan interaksi antara pengguna dengan sistem dalam mengendalikan pergerakan karakter pada game tersebut melalui sebuah controller. Namun untuk orang dengan keterbatasan fisik, controller menjadi sebuah halangan untuk dapat berkomunikasi dengan sistem. Salah satu teknologi yang dapat digunakan untuk mengatasinya yaitu menggunakan Brain Computer Interface (BCI) yang pada perkembangannnya dapat dimanfaatkan untuk pengendalian karakter pada video game. BCI terdiri dari komponen input dari sinyal otak, komponen output berupa perintah dan komponen intermediate. Persoalan utama BCI terletak pada komponen intermediate yang biasanya menggunakan Elektroensephalogram (EEG). Bentuk sinyal EEG pada setiap orang dapat bervariasi dan kompleks tergantung kondisi kesehatan, emosional, usia, mental dan aktivitas. Beberapa penelitian terdahulu menggunakan sinyal EEG untuk menggerakkan video game pada perangkat mobile, menggerakkan kursor dan mengendalikan robot. Kontrol gerak EEG sebelumnya menggunakan kondisi emosional, namun kondisi emosional tidak menggambarkan aksi karakter secara nyata. Penelitian ini telah membuat sistem kontrol gerak karakter menggunakan sinyal EEG yang diimplementasikan pada video game dengan aksi karakter setiap 1 detik. Dalam proses akuisisi data yang dilakukan terhadap 10 Naracoba selama 1 menit dengan 3 kali perulangan, Naracoba membayangkan 3 gerakan bergantian setiap 5 detik. Hasil akurasi dari 360 set data latih sebesar $77 \%$ dan data baru menghasilkan akurasi sebesar $67 \%$.
\end{abstract}

Kata kunci-Brain Computer Interface; Learning Vector Quantization; Sinyal EEG; Spektral Daya; Video Game.

\section{PENDAHULUAN}

Video game adalah permainan elektronik yang membutuhkan interaksi antara player dengan sistem melalui controller untuk menghasilkan umpan balik secara visual. Controller menjadi perangkat yang harus ada dalam sebuah permainan elektronik, karena merupakan sarana untuk mengendalikan, memerintah dan mengatur keadaan dari suatu sistem dan tidak jarang pengembangan pada sistem controller menjadi suatu nilai tambah pada sebuah perangkat video game.

Brain Computer Interface (BCI) merupakan suatu teknologi untuk mengontrol suatu perangkat eksternal tanpa menggunakan otot, suara dan fungsi motorik lainnya. BCI terdiri dari komponen input dari sinyal otak, komponen output berupa perintah dan komponen intermediate. Persoalan utama BCI terletak dari komponen antara atau intermediate, yang biasanya menggunakan Elektroensephalogram (EEG). Dalam pengembangannya, BCI dapat dimanfaatkan untuk pengendalian karakter pada video game, seperti pada penelitian terdahulu mengenai BCI yaitu untuk mengendalikan video game pada perangkat mobile [1]. Terdapat pula penelitian mengenai pengendalian video game multi-player 3-D yang dikendalikan oleh fitur EEG terkait dengan tiga tingkat perhatian [2] strategi pada permainan catur [3].

EEG merupakan instrumen untuk merekam aktivitas listrik di otak sehingga mempunyai amplitudo yang rendah. Bentuk sinyal EEG pada setiap orang dapat bervariasi dan kompleks tergantung kondisi kesehatan, emosional, usia, mental dan aktivitas. Komponen frekuensi dari sinyal EEG dapat menginformasikan kondisi pikiran. Oleh karena itu, ekstraksi sinyal EEG kedalam komponen waktu menjadi sangat berguna. Beberapa penelitian terdahulu menggunakan ekstraksi frekuensi untuk mengidentifikasikan sinyal EEG terhadap rangsangan suara [4], aksi menggerakkan karakter dalam game arcade [5], mengukur traumatis cedera otak ringan [6], mengetahui tingkat perhatian siswa [7], identifikasi kondisi rileks [8], Membedakan kondisi antara membuka mata dan menutup mata [9]. 
Perkembangan wireless EEG menjadikan penggunaan BCI menjadi sangat menarik. Terdapat penelitian terdahulu mengenai BCI yaitu untuk mengendalikan robot [10], BCI pada aplikasi manufaktur [11], membayangkan gerakan tangan [12] dan menggerakan kursor dengan membayangkan gerakan jari dan lengan [13].

Penelitian ini berfokus pada identifikasi tiga kondisi pikiran saat membayangkan gerakan yang direkam melalui sinyal EEG sebagai perangkat BCI. BCI untuk menggerakan karakter telah dilakukan pada penelitian terdahulu menggunakan kondisi emosional [5], namun penelitian tersebut tidak berfokus pada kondisi saat seseorang sedang membayangkan gerakan karakter. Penelitian tersebut dikembangkan dalam penelitian ini untuk mengidentifikasi kondisi saat seseorang sedang membayangkan gerakan karakter dan direpresetasikan kedalam video game.

Sistem identifikasi yang telah dibangun untuk pemrosesan sinyal EEG sebagai perangkat intermediete menggunakan Spektral Daya dan Learning Vector Quantization (LVQ). Beberapa penelitian terdahulu dalam sistem BCI diantaranya menggunakan ekstraksi Discrete Wavelet Transform (DWT) dan K-Nearest Neighbor (KNN) [14], DWT dan Support Vector Machine (SVM) [15], Fast Fourier Transform (FFT) dan LVQ [5]. Spektral Daya dan LVQ digunakan karena memiliki akurasi yang besar dan waktu komputasi yang cukup singkat mengingat aksi pada video game dilakukan secara real time.

Sistem identifikasi dibangun dengan melakukan pelatihan terlebih dahulu menggunakan sinyal EEG yang direkam dari 10 Naracoba dan tiga kali perulangan sebagai data latih. Perekaman dilakukan dengan memberikan video berupa perintah untuk membayangkan gerakan maju, berhenti dan melompat secara bergantian setiap lima detik.

\section{METODE}

\section{A. Perancangan Sistem Identifikasi}

Perancangan sistem kontrol gerak pada video game berdasarkan sinyal EEG menggunakan ekstraksi Spektral Daya dan LVQ menggunakan komponen sinyal gelombang Teta $(4-7 \mathrm{~Hz})$, gelombang Alfa $(8-12 \mathrm{~Hz})$, gelombang Beta $(13-30 \mathrm{~Hz})$ dan gelombang Gamma Low $(31-40 \mathrm{~Hz})$. Hasil ini didapat melalui proses ekstraksi Spektral Daya berupa gelombang Teta berjumlah 4 data, gelombang Alfa sebanyak 5 data, gelombang Beta sebanyak 18 data dan gelombang Gamma Low sebanyak 10 data.

Masukan sistem dari penelitian ini berupa data rekaman sinyal gelombang otak dari 10 naracoba menggunakan wireless EEG dengan frekuensi sampling $128 \mathrm{~Hz}$. Perekaman data latih dan data uji dilakukan secara offline dikarenakan pelatihan dan pengujian sistem dilakuak secara offline

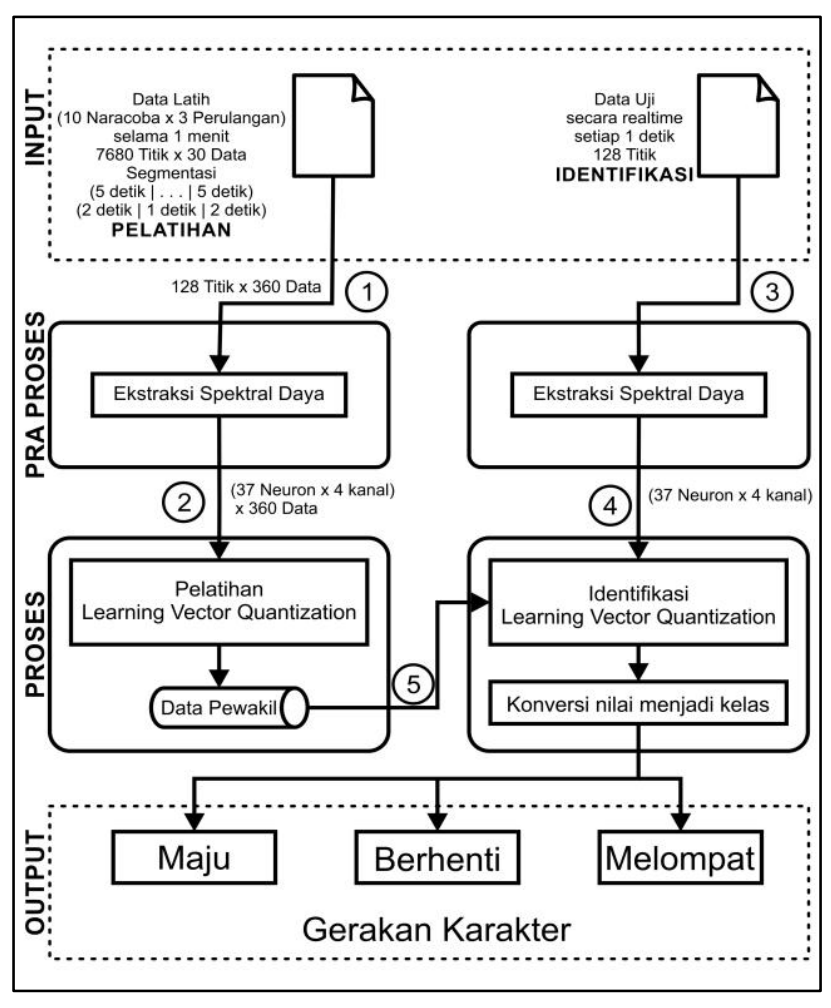


Dilakukan praproses pada data masukan dengan membagi 1 menit data rekaman menjadi 1 detik perekaman yang diambil setiap lima detik sekali sehingga setiap naracoba menghasilkan data sebanyak 1.536 titik sinyal. Kemudian data tersebut diekstraksi setiap satu detik menggunakan Spektral Daya dan menghasilkan 37 neuron.

Neuron yang dihasilkan pada praproses digunakan untuk pelatihan menggunakan LVQ. Hasil dari proses pelatihan adalah data pewakil untuk masing-masing kelas yang disimpan di dalam basis data. Data pewakil tersebut digunakan untuk proses identifikasi menggunakan LVQ.

\section{B. Brain Computer Interface}

BCI adalah suatu teknologi yang memanfaatkan gelombang otak manusia untuk mengendalikan perangkat eksternal. Sistem BCI terdiri dari komponen input dari sinyal otak, komponen output berupa perintah, dan komponen intermediate.

Setiap orang mampu mengontrol hanya dengan gelombang otak atau pikiran, dengan kata lain untuk mengontrol suatu alat/mesin tidak perlu melakukan aktifitas fisik. Pada awal perancangan BCI, sistem ini diharapkan dapat digunakan untuk sarana komunikasi bagi penderita lumpuh total, untuk rehabilitasi, dan dapat juga dimanfaatkan untuk teknik kendali dalam permainan komputer. Sebuah sistem BCI terdiri dari pengukuran sinyal otak, dan kemudian dilakukan sistem pengolahan sinyal otak tersebut untuk mendeteksi pola - pola unik yang akan diterjemahkan menjadi perintah, seperti pola otak saat fokus/konsentrasi atau rileks.

Penelitian terdahulu mengenai BCI menggunakan ektraksi Wavelet sehingga diperoleh akurasi yang cukup tinggi, yaitu 99\% [14], sementara penelitian lain menggunakan ekstraksi Discrete Wavelet Transform (DWT) dan K-Nearest Neighbor (KNN) untuk membedakan dua kelas [15], kontrol kursor menggunakan ekstraksi DWT, identifikasi menggunakan SVM yang membedakan lima kelas gerakan kursor secara realtime [16]. Penelitian lain menggunakan Fast Fourier Transform (FFT) dan LVQ untuk menggerakkan game arcade. Penelitian tersebut telah diuji dengan akurasi sebesar $90 \%$ untuk kondisi rileks dan $22 \%$ untuk kondisi fokus [17].

\section{Electroensephalogram}

EEG adalah alat untuk merekam aktivitas listrik spontan dari otak, yang digunakan dalam bidang medik, psikologi dan kesehatan. Bentuk sinyal EEG pada setiap orang sangat bervariasi. Hal tersebut dipengaruhi karena kondisi pikiran, kondisi kesehatan dan rangsangan dari luar. Perangkat ini menggunakan sensor yang disebut elektroda, yang dipasang di permukaan kulit kepala. Sinyal EEG mempunyai amplitude yang kecil, mudah tertimbun noise, dan tidak mempunyai bentuk baku yang merefleksikan kondisi otak. Perangkat EEG yang digunakan adalah Emotiv Insight yang dapat dilihat pada Gambar 2.

Sinyal EEG mempunyai komponen frekuensi yang menggambarkan kondisi pikiran. Gelombang Delta (0.5-3 $\mathrm{Hz})$ muncul saat seseorang sedang tidur nyenyak, gelombang Teta $(4-7 \mathrm{~Hz})$ muncul saat seseorang sedang tidur ringan atau dalam keadaan stres emosional, gelombang Alfa $(8-13 \mathrm{~Hz})$ muncul saat dalam keadaan rileks, gelombang Beta $(14-30 \mathrm{~Hz})$ muncul saat seseorang sedang berpikir, gelombang Gamma $(>30 \mathrm{~Hz})$ muncul saat seseorang dalam kesadaran penuh. Oleh karena itu, representasi sinyal EEG ke dalam domain frekuensi menjadi berguna untuk mengolah sinyal EEG untuk mendapatkan kondisi pikiran tertentu. Set-up sistem pengukuran sinyal EEG biasanya menggunakan standar International Federation of Societes of Electroencephalography, dimana elektroda ditempatkan pada kulit kepala pada posisi/aturan standar yaitu sistem 10-20 seperti pada Gambar 3 .

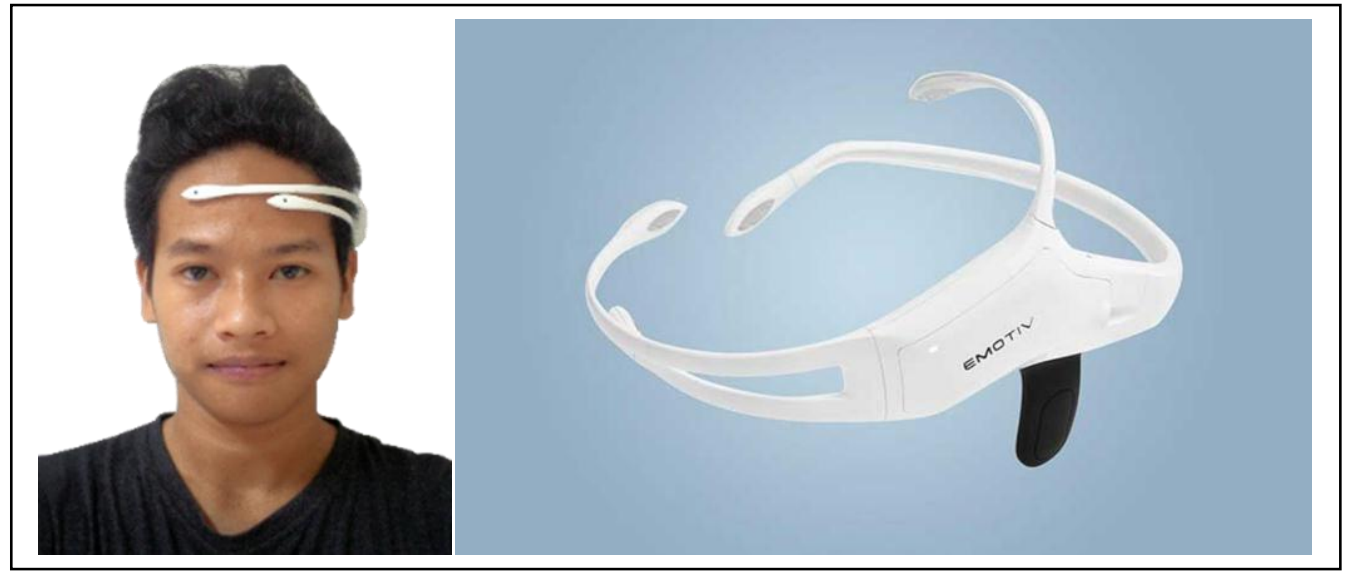




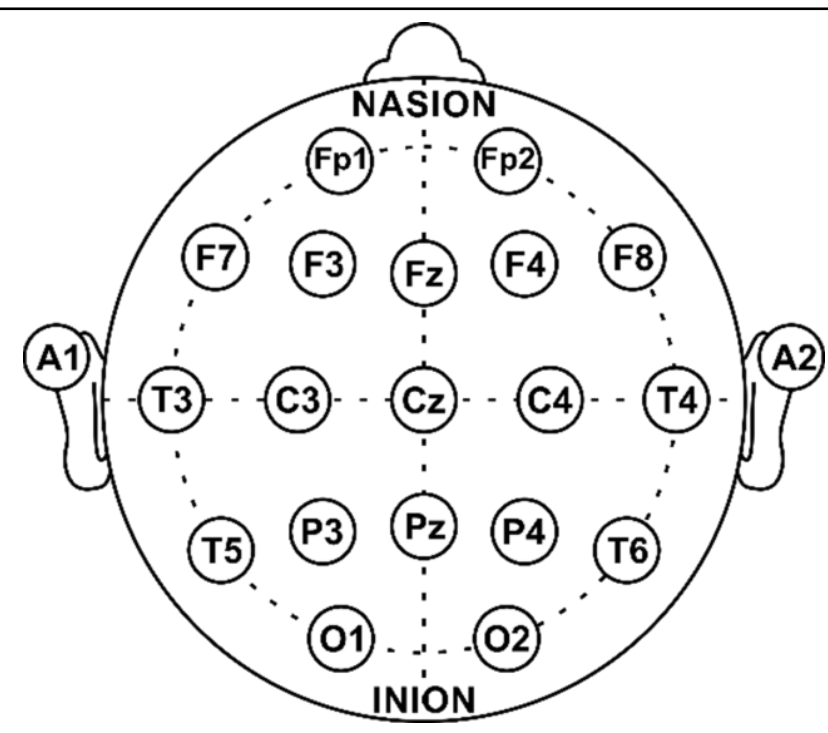

Gambar 3. Penempatan elektroda sistem 10-20

Terdapat penelitian terdahulu dalam pengolahan sinyal EEG, pada penelitian tersebut menggunakan wireless EEG sistem 10-20 dengan dua kanal, yaitu Fp1 dan Fp2 [5].

Sedangkan pada penelitian ini perangkat wireless EEG yang digunakan menggunakan sistem Modified Combinatorial Nomenclature (MCN) yang merupakan pengembangan sistem 10-20 dimana sistem MCN lebih terperinci dengan elektroda yang lebih banyak. Tetapi pada perangkat ini hanya menggunakan kanal AF3, AF4, T7, T8 dan Pz yang dapat dilihat pada Gambar 4.

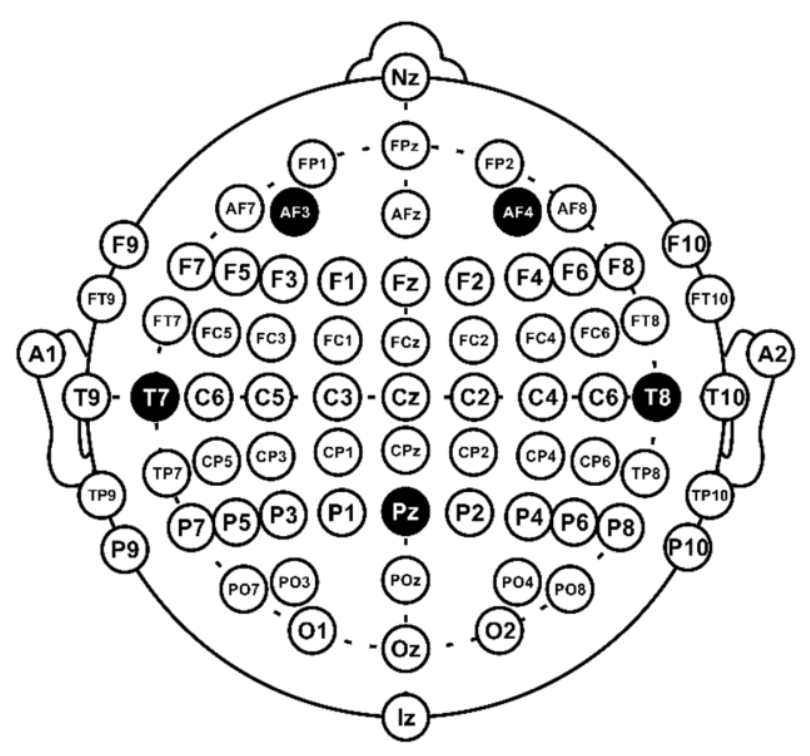

Gambar 4. Penempatan elektroda sistem MCN

\section{Akuisisi Data}

Pengambilan data EEG dilakukan dengan wireless EEG menggunakan kanal AF3, AF4, T7 dan T8, dengan frekuensi sampling $128 \mathrm{~Hz}$ yang dipasang di permukaan kulit kepala untuk merekam sinyal dalam otak terhadap 10 naracoba untuk data latih dan 5 naracoba untuk data uji dengan tiga kali perulangan.

Perekaman dilakukan selama 60 detik. Perekaman dilakukan dengan memperhatikan sebuah video instruksi yang akan menampilkan perintah gerakan yang harus dibayangkan oleh naracoba. Selama 60 detik, naracoba akan 
membayangkan tiga gerakan secara bergantian setiap lima detik. Selanjutnya untuk waktu perulangan perekaman terhadap sepuluh naracoba yang dilakukan dibagi menjadi tiga waktu berbeda.

\section{E. Segmentasi}

Sinyal EEG yang telah direkam disegmentasi setiap lima detik menjadi 12 segmen untuk membagi data rekaman menjadi tiga kelas. Setelah data disegmentasi lima detik, dilakukan segmentasi lanjutan dengan segmentasi setiap satu detik dan menghilangkan dua detik diawal dan dua detik diakhir sehingga hanya menyisakan satu detik data dalam setiap segmen. Hal ini dilakukan untuk menyesuaikan panjang data latih dengan data uji saat dilakukan identifikasi. Segmentasi sinyal EEG dapat dilihat pada Tabel 1.

TABEL 1. SEGMENTASI SinYAL EEG

\begin{tabular}{|c|c|c|c|c|c|c|c|}
\hline \multirow{2}{*}{ No. } & \multirow{2}{*}{ Waktu } & \multicolumn{4}{|c|}{ Data Sinyal EEG } & \multirow{2}{*}{$\mathbf{S}$} & \multirow{2}{*}{$\mathbf{K}$} \\
\hline & & AF3 & AF4 & T7 & T8 & & \\
\hline 1 & 0.0078 & -28 & 45 & -227 & 16 & \multirow{3}{*}{1} & \multirow{3}{*}{$\mathrm{M}$} \\
\hline & & & & & 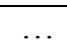 & & \\
\hline 640 & 5.0000 & 128 & -106 & -19 & 85 & & \\
\hline 641 & 5.0078 & 108 & -110 & -123 & 68 & \multirow{3}{*}{2} & \multirow{3}{*}{ B } \\
\hline & & & $\ldots$ & & $\ldots$ & & \\
\hline 1.280 & 10.5000 & -3 & 7 & 22 & 37 & & \\
\hline 1.281 & 10.5078 & 13 & 11 & 126 & 53 & \multirow{3}{*}{3} & \multirow{3}{*}{$\mathrm{L}$} \\
\hline & & & 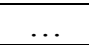 & & . & & \\
\hline 1.920 & 15.0000 & -17 & 99 & -108 & 53 & & \\
\hline & & & & & $\ldots$ & $\ldots$ & $\ldots$ \\
\hline 7.041 & 55.0078 & -7 & 102 & -4 & 76 & \multirow{3}{*}{12} & \multirow{3}{*}{$\mathrm{L}$} \\
\hline & & & & & $\ldots$ & & \\
\hline 7.680 & 60.0000 & 57 & 73 & -11 & 108 & & \\
\hline
\end{tabular}

Keterangan :

$\begin{array}{lll}\mathrm{S}=\text { Segmen } & \mathrm{B}=\text { Berhenti } \\ \mathrm{K}=\text { Kelas } & \mathrm{L}=\text { Lompat } \\ \mathrm{M}=\text { Maju } & \end{array}$

\section{F. Spektral Daya}

Sinyal EEG adalah sinyal non stasioner. Salah satu metode konversi domain waktu ke dalam domain frekuensi adalah Spektral Daya, yang mempunyai waktu komputasi cukup singkat. Namun, metode tersebut lebih tepat ditujukan untuk sinyal stasioner. Walaupun demikian, apabila sinyal EEG diproses dalam waktu yang singkat, maka pendekatan metode stasioner seperti FFT dapat digunakan [4]. Proses analisa menggunakan Spektral Daya terdiri dari beberapa tahap yaitu frame based, windowing, FFT dan Analisis Spektral.

\section{1) Frame Based}

Frame based yaitu proses membagi sinyal menjadi beberapa frame. Untuk meminimalkan diskontinuitas sinyal dilakukan overlap, biasanya panjang daerah overlap yang umum digunakan adalah kurang lebih $30 \%$ - 50\% dari panjang frame menggunakan Persamaan 1. Pada penelitian ini overlap yang digunakan sebesar $50 \%$ yang didasari dari beberapa penelitian terdahulu yang telah dilakukan [17]. Selanjutnya menghitung hasil akhir dari frame based menggunakan Persamaan 2.

$$
\begin{aligned}
& M=N * \text { Overlap } \\
& X(n)=y(M+n)
\end{aligned}
$$

Keterangan :

$M \quad$ = menyatakan overlaping frame

$N \quad=$ menyatakan jumlah data

$n \quad=$ menyatakan indeks data

$y(n)=$ menyatakan nilai sinyal hasil perekaman

$x(n)=$ menyatakan hasil Frame Based.

2) Windowing

Windowing digunakan untuk meminimalkan pengaruh fluktuasi pada sidelobe yang dapat mengganggu resolusi spektral terestimasi. Pada dasarnya Windowing membagi sinyal atas frame yang panjang datanya sama. Salah satu 
jenis windowing yang digunakan yaitu Hamming dengan kesederhanaan dan hasil dari windowing yang baik, seperti pada Persamaan 3 dan Persamaan 4.

$$
\begin{gathered}
w(n)=0.54-0.46 \cos \left(\frac{2 \pi n}{N-1}\right), 0 \leq n \leq N-1 \\
y(n)=y * w(n)
\end{gathered}
$$

Keterangan :

$w(n) \quad=$ menyatakan nilai Hamming window ke- $n$

$N=$ menyatakan jumlah sampel setiap frame

$n \quad=$ menyatakan indeks sampel suatu frame

$z(n)=$ menyatakan sinyal hasil Windowing sampel ke- $n$

\section{3) Fast Fourier Transform}

FFT adalah algoritma yang mengimplementasikan Discrete Fourier Transform (DFT) dan bertujuan untuk mengkonversi setiap frame dari domain waktu ke domain frekuensi menggunakan Persamaan 5.

$$
X(k)=\frac{1}{N} \sum_{n=0}^{N-1} x_{n}\left[\left(\cos \frac{2 \pi k n}{N}\right)-j\left(\sin \frac{2 \pi k n}{N}\right)\right]
$$

Keterangan :

$X(k)=$ menyatakan nilai titik frekuensi ke- $k$

$k=$ menyatakan indeks suatu frekuensi

$\mathrm{N}$ = menyatakan jumlah sampel setiap frame

$\mathrm{n} \quad=$ menyatakan indeks sampel suatu frame

$z_{n} \quad=$ menyatakan sinyal hasil Windowing sampel ke- $n$

4) Analisis Spektral

Analisis spekral adalah analisis runtun waktu yang dapat menguraikan data pada berbagai frekuensi yang dapat digunakan untuk mencari periodisitas tersembunyi. Salah satu metode analisis sektral adalah metode Welch menggunakan Persamaan 6.

$$
S_{x}=\frac{1}{k} \sum_{k=1}^{k} y(n)
$$

Keterangan :

$\mathrm{S}_{\mathrm{x}}=$ hasil Analisa Spektral titik frekuensi ke-x

$\mathrm{k} \quad=$ menyatakan jumlah frame

$\mathrm{y}(\mathrm{n})=$ menyatakan nilai titik frekuensi ke-n suatu frame

Metode Welch didasarkan pada konsep penggunaan estimasi spektrum periodogram yang merupakan hasil konversi sinyal dari domain waktu ke domain frekuensi. Metode Welch mengambil nilai rata-rata hasil dari FFT pada tiap frame.

\section{G. Jaringan Syaraf Tiruan}

Jaringan Syaraf Tiruan (JST) adalah paradigma pemrosesan suatu informasi yang terinspirasi oleh sistem sel syaraf biologi, sama seperti otak yang memproses suatu informasi. Elemen mendasar dari paradigma tersebut adalah struktur yang baru dari sistim pemrosesan informasi. JST memiliki sifat seperti manusia yaitu belajar dari suatu contoh. JST dibentuk untuk memecahkan suatu masalah tertentu seperti pengenalan pola atau klasifikasi karena proses pembelajaran.

Penggunaan JST dalam melakukan klasifikasi dan identifikasi memiliki beberapa kelebihan di antaranya mampu mengakuisisi pengetahuan walau tidak ada kepastian, mampu melakukan generalisasi dan ekstraksi dari suatu pola data tertentu, JST juga dapat menciptakan suatu pola pengetahuan melalui pengaturan diri atau kemampuan belajar (self organizing).

Terdapat beberapa macam jenis Jaringan Syaraf Tiruan salah satunya yang digunakan pada penelitian ini adalah metode LVQ.

\section{1) Learning Vector Quantization}


Metode LVQ digunakan untuk pengelompokan dengan jumlah target atau kelas sudah ditentukan sebelumnya. Metode klasifikasi ini termasuk supervise learning, karena data latih telah diklasifikasikan terlebih dahulu, yang terdiri dari lapisan input dan lapisan kompetitif. Prinsip kerja dari algoritma LVQ adalah pengurangan node - node yang pada akhirnya hanya ada satu node output yang terpilih. Pada penelitian sebelumnya proses pembelajaran menggunakan metode LVQ setiap vektor gambar dipelajari dan menghasilkan satu vektor nilai data pewakil dengan banyaknya pengujian 25 kali untuk setiap parameter [18].

Suatu lapisan kompetitif secara otomatis belajar untuk mengklasifikasikan vektor-vektor masukan. Kelas-kelas yang didapatkan sebagai hasil dari lapisan kompetitif ini hanya tergantung pada jarak antara vektor-vektor masukan dengan vektor data pewakil, yang kemudian data pewakil dari kelas pemenang direvisi. Jika dua vektor masukan mendekati sama, maka lapisan kompetitif meletakkan kedua vektor masukan tersebut ke dalam kelas yang sama. Arsitektur jaringan LVQ dapat dilihat pada Gambar 5.

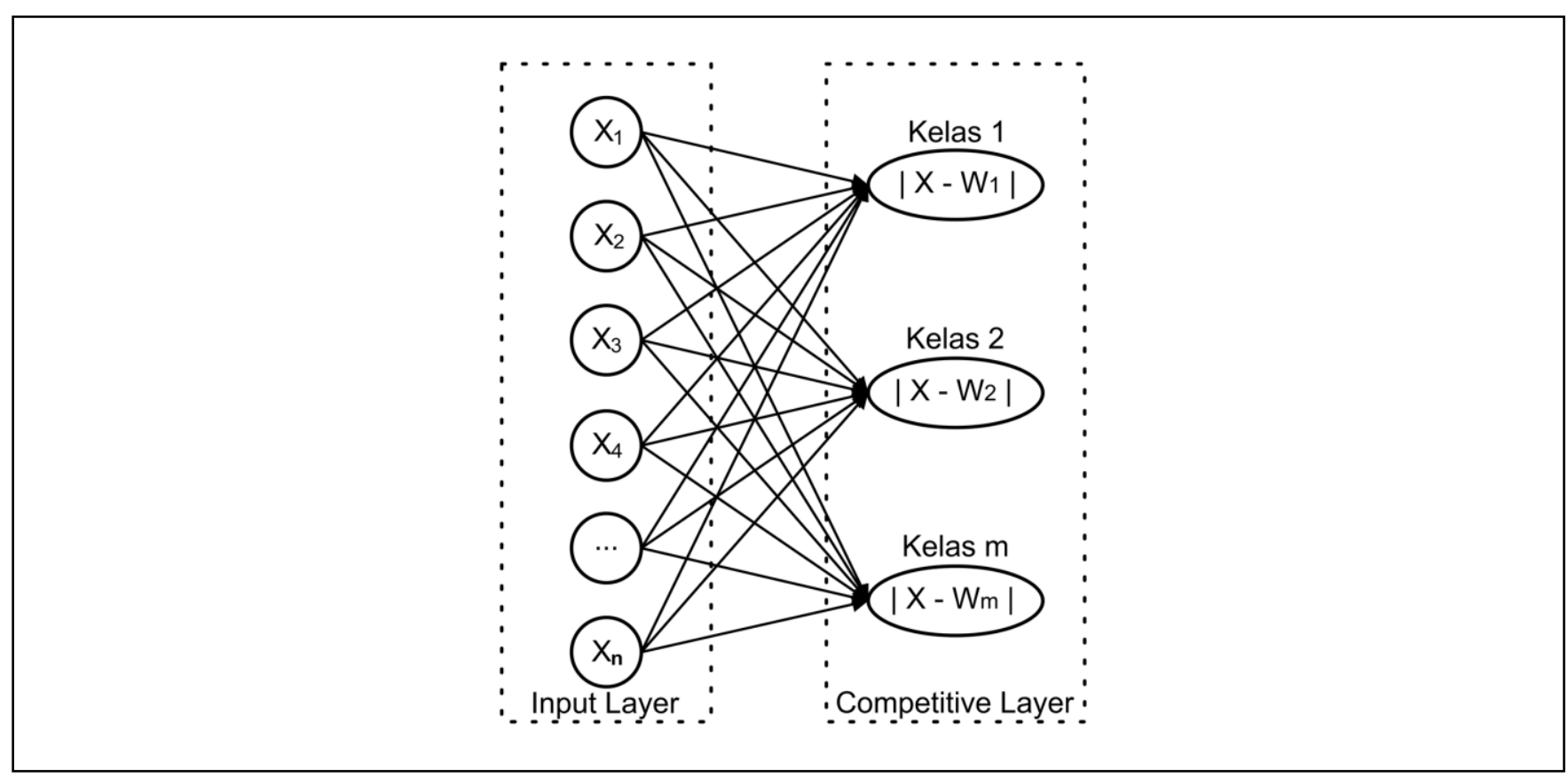

Gambar 5. Arsitektur LVQ

Tahap pembelajaran LVQ, pertama inisialisasi bobot yang tidak lain adalah pewakil data latih setiap kelas. Setelah menentukan bobot, maka jaringan diberi setiap set data latih sebagai neuron input. Setelah input diterima jaringan, maka jaringan mulai melakukan perhitungan jarak vektor yang didapatkan dengan jarak antara vektor input dengan vektor bobot menggunakan Persamaan 7.

$$
\text { jarak }=\sqrt{\sum_{i=1}^{n}\left(x_{i}-w_{i}\right)^{2}}
$$

Pada saat pembelajaran hanya bobot pemenang dengan nilai minimum yang dilakukan revisi. Apabila kelas pemenang sama dengan kelas sebenarnya maka menggunakan Persamaan 8, dan apabila kelas pemenang berbeda dengan kelas sebenarnya digunakan Persamaan 9.

$$
\begin{aligned}
& W_{j}(\text { baru })=W_{j}(\text { lama })+a\left(x-W_{j}(\text { lama })\right) \\
& W_{j}(\text { baru })=W_{j}(\text { lama })-a\left(x-W_{j}(\text { lama })\right)
\end{aligned}
$$

Setelah semua data telah dilatih seluruhnya untuk iterasi pertama, maka dilakukan pengurangan laju pembelajaran untuk setiap iterasi dengan menggunakan Persamaan 10.

$$
\alpha=\alpha-0.1 * \alpha
$$

Proses penghentian pembelajaran dilakukan jika nilai $\alpha$ telah lebih kecil dari nilai minimum error (Eps) yang telah ditetapkan sebelumnya atau telah mencapai iterasi maksimum yaitu 10 iterasi. Terdapat penelitian terdahulu yang menggunakan LVQ untuk mengidentifikasi hasil ekstraksi Wavelet menjadi dua kelas, yaitu kelas rileks dan 
tidak rileks. Hasil pengujian menggunakan 10 data baru didapatkan akurasi sebesar $47 \%$ dan pengujian terhadap data latih sebesar $87 \%$ [8].

\section{HASIL DAN DISKUSI}

\section{A. Implementasi Sistem}

Implementasi perangkat lunak terhadap sistem yang telah dirancang menggunakan UML. Perangkat lunak ini dibagi menjadi dua bagian, perangkat lunak untuk identifikasi EEG berbasis desktop menggunakan bahasa Pemrograman Java dengan IDE Eclipse dan basis data SQLite, sedangkan perangkat lunak untuk implementasi video game berbasis desktop menggunakan bahasa Pemrograman C\# dengan IDE Unity3D dan Monodevelop.

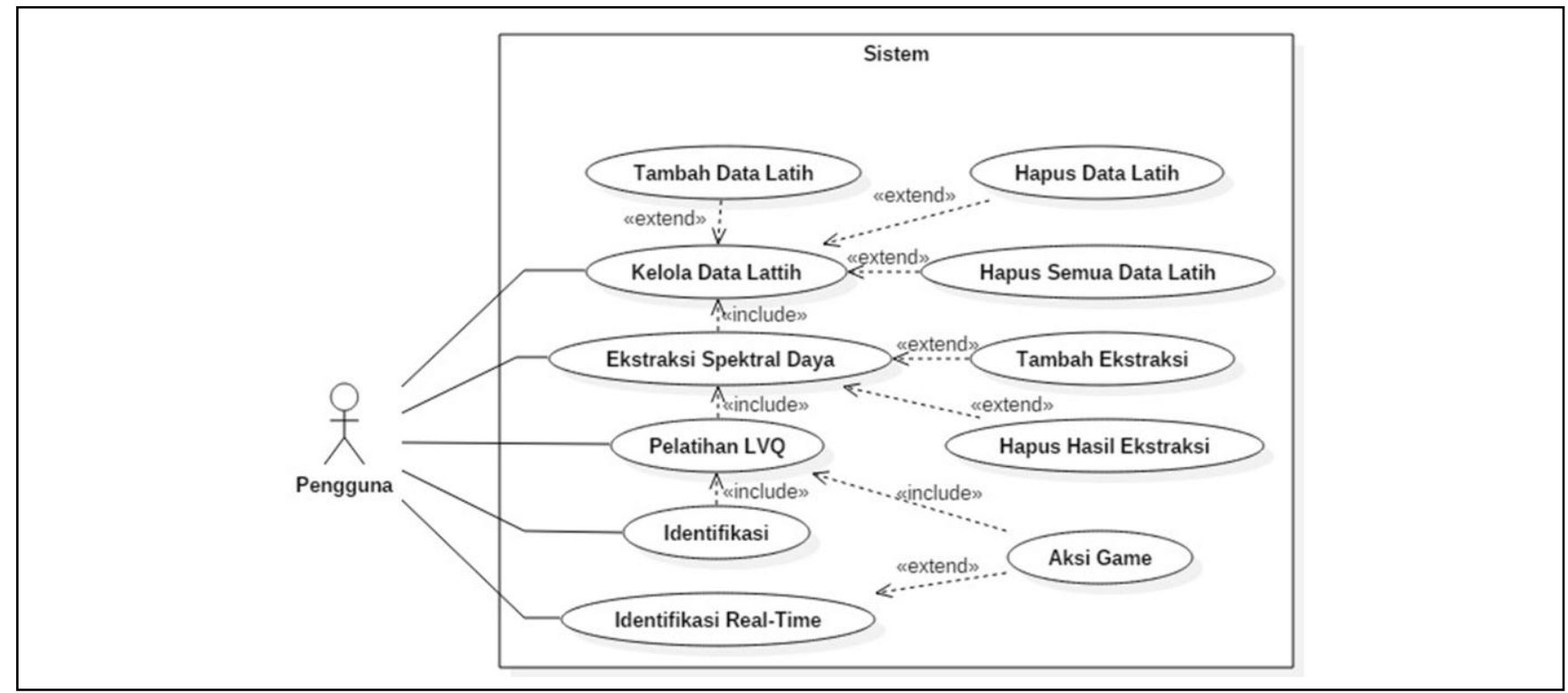

Gambar 6. Sistem Identifikasi Kontrol Gerak Karakter

Sistem kontrol gerak karakter dengan menggunakan Sinyal EEG dimulai dengan praproses yaitu dilakukan proses input data latih hasil perekaman selama satu menit yang dibagi ke dalam lima detik perekaman. Setiap lima detik perekaman dilakukan segmentasi dengan menghilangkan dua detik diawal dan dua detik diakhir perekaman, sehingga setiap naracoba menghasilkan 12 segmen dengan data sebanyak 1.536 titik sinyal yang disimpan dalam basis data. Implementasi kelola data latih dapat dilihat pada Gambar 7.

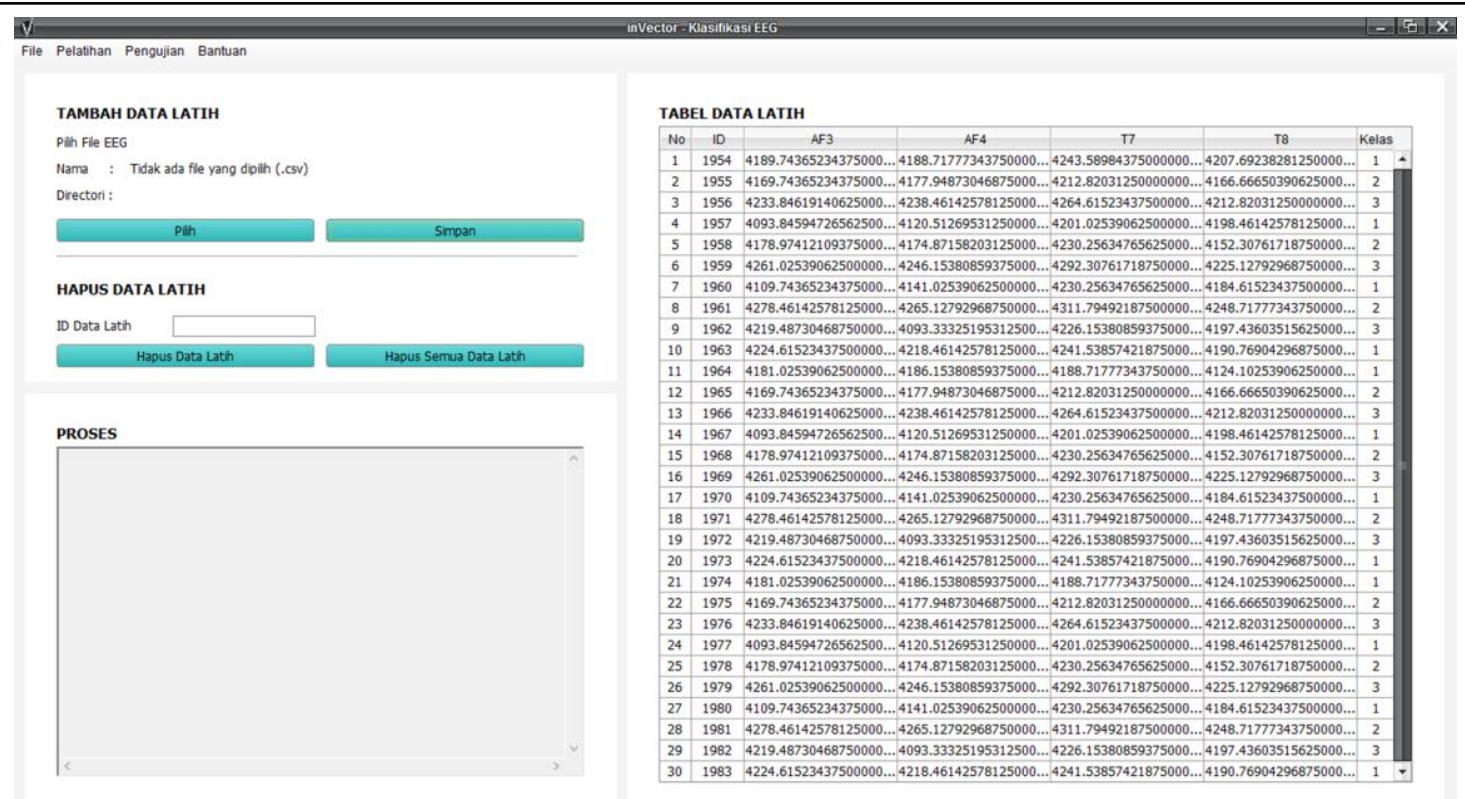

Gambar 7. Implementasi Kelola Data Latih 
Kemudian data hasil segmentasi tersebut diekstraksi setiap satu detik menggunakan Spektral Daya dan menghasilkan 37 neuron yang digunakan untuk masukan saat pelatihan menggunakan metode LVQ. Implementasi proses ekstraksi menggunakan Spektral Daya dapat dilihat pada Gambar 8.

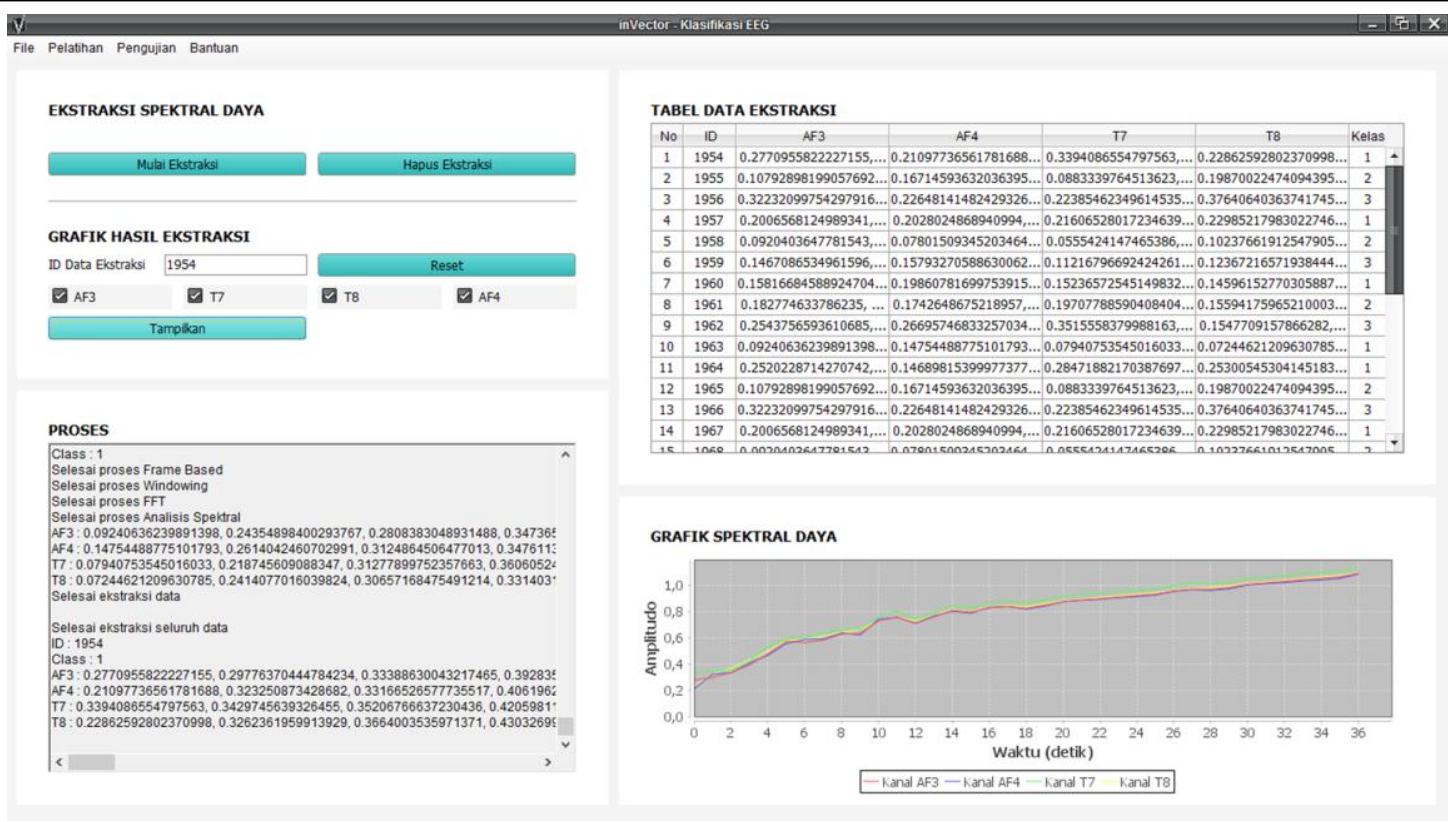

Gambar 8. Implementasi Ekstraksi Spektral Daya

Hasil dari pelatihan LVQ berupa data pewakil dari tiga kelas yang kemudian disimpan ke dalam basis data yang nantinya digunakan sebagai nilai pembanding dalam proses identifikasi. Implementasi proses pelatihan LVQ dapat dilihat pada Gambar 9.

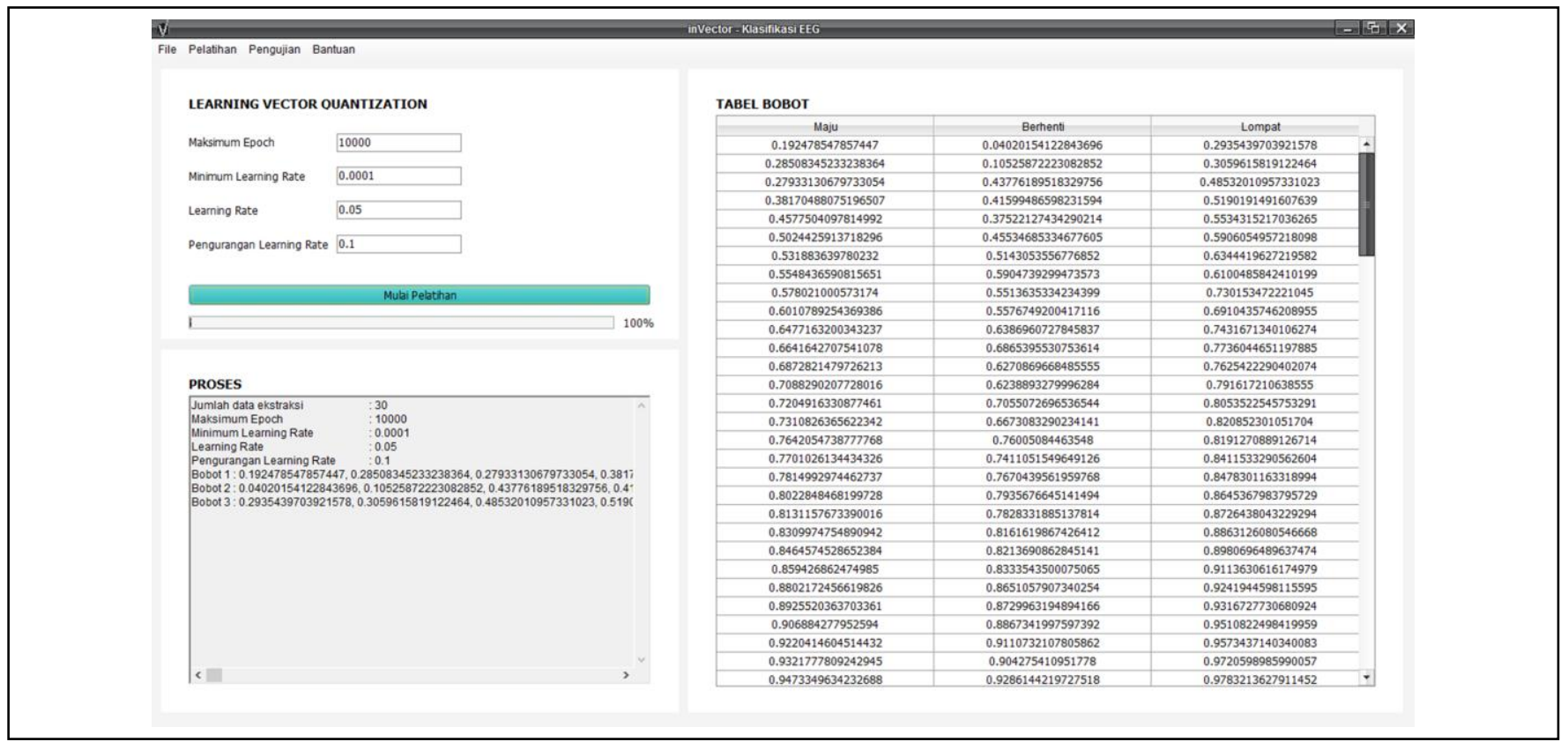

Gambar 9. Implementasi Pelatihan LVQ

Pada tahap identifikasi, dilakukan ekstraksi menggunakan Spektral Daya. Hasil dari ekstraksi berupa 37 neuron yang akan diidentifikasi menggunakan LVQ berdasarkan data pewakil setiap kelas yang didapatkan dari proses pelatihan. Impelemtasi proses identifikasi dapat dilihat pada Gambar 10. 


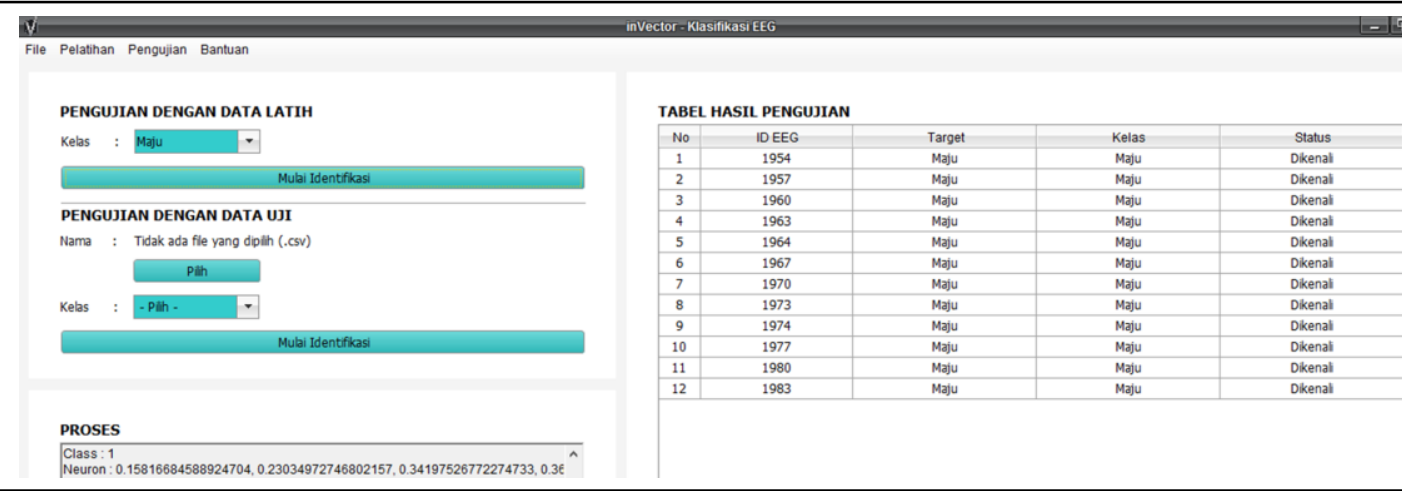

Gambar 10. Implementasi Identifikasi

Pada tahap identifikasi real time, dimulai dengan pengambilan data EEG secara real time setiap 1 detik menggunakan wireless EEG yang dipakai saat menggunakan sistem identifikasi real time, selanjutnya dilakukan segmentasi terhadap data yang telah diperoleh dan dilakukan ekstraksi menggunakan Spektral Daya. Hasil dari ekstraksi berupa 37 neuron yang akan diidentifikasi menggunakan LVQ. Hasil identifikasi akan divisualisasikan dalam aksi karakter pada implementasi real time. Impelemtasi proses identifikasi real time dapat dilihat pada Gambar 11 .

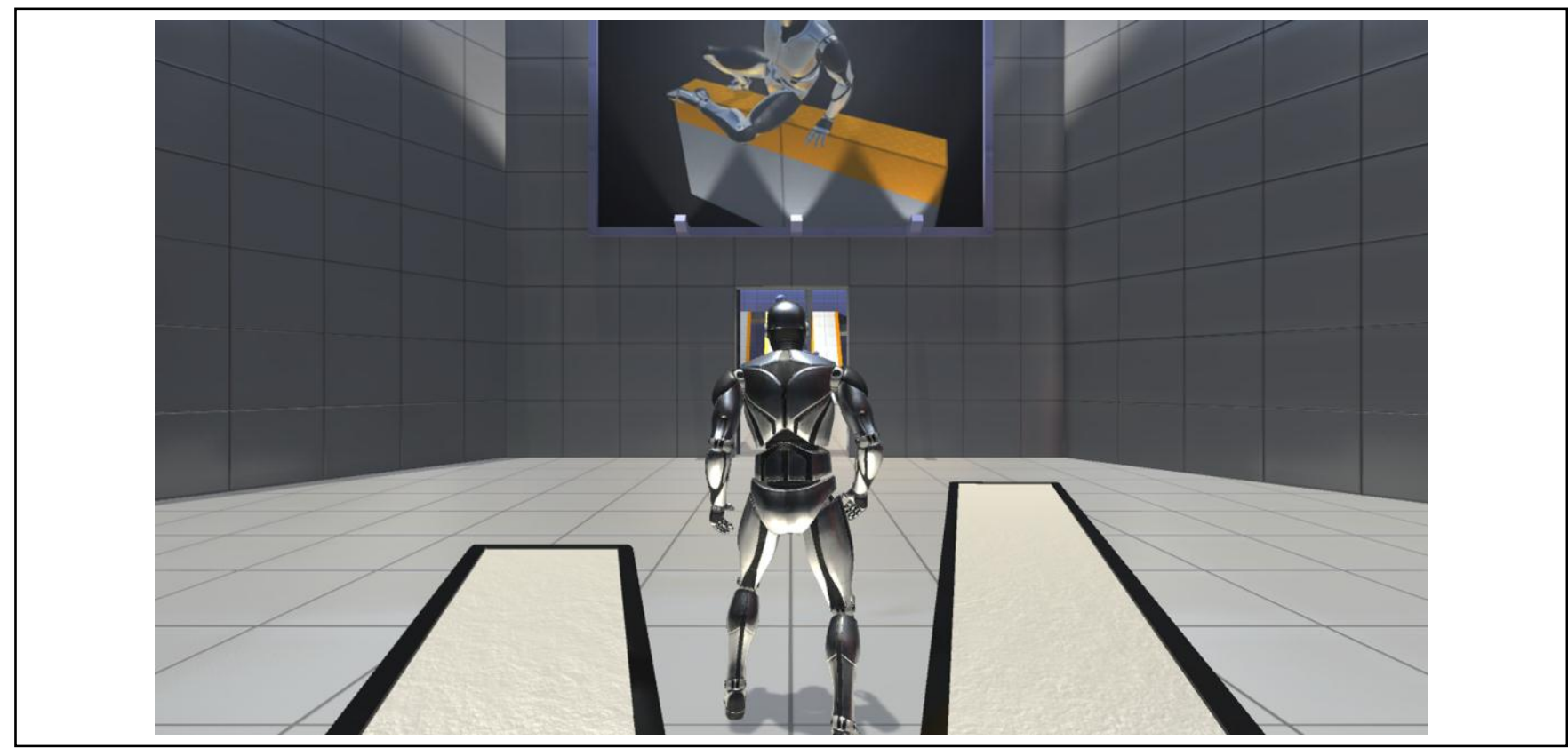

Gambar 11. Implementasi Identifikasi Real Time

\section{B. Pengujian Akurasi Sistem}

Data latih yang digunakan dalam penelitian ini sebanyak 360 set data latih yang diperoleh dari 10 naracoba dengan mengikuti perintah yang ditampilkan dalam sebuah video untuk membayangkan gerakan maju, berhenti dan melompat. Perekaman dilakukan sebanyak tiga kali perulangan.

Pelatihan terhadap data latih menggunakan LVQ dengan learning rate 0.01-0.05 dengan pengurangan learning rate 0.01-0.1. Analisa parameter LVQ dapat dilihat pada Tabel 2.

TABEL 2. ANALISIS PARAMETER LVQ

\begin{tabular}{|c|c|c|c|c|}
\hline \multirow{2}{*}{ No } & \multirow{2}{*}{ Learning rate } & $\begin{array}{c}\text { Konstanta Pengurangan } \\
\text { Learning rate }\end{array}$ & \multicolumn{2}{|c|}{ Tingkat Akurasi Pengujian (\%) } \\
\cline { 3 - 5 } & 0.05 & 0.1000 & Data Latih & Data Uji \\
\hline 1 & 0.04 & 0.1000 & 75 & 54 \\
\hline 2 & 0.03 & 0.1000 & 75 & 54 \\
\hline 3 & \multicolumn{2}{|c}{} \\
\hline
\end{tabular}




\begin{tabular}{|c|c|c|c|c|}
\hline No & Learning rate & Konstanta Pengurangan & \multicolumn{2}{c|}{ Tingkat Akurasi Pengujian (\%) } \\
\hline 4 & 0.02 & 0.1000 & 75 & 50 \\
\hline 5 & 0.01 & 0.1000 & 75 & 55 \\
\hline 6 & 0.01 & 0.0500 & 62 & 50 \\
\hline 7 & 0.01 & 0.0100 & 48 & 40 \\
\hline
\end{tabular}

Hasil analisa pada Tabel 2 menunjukan bahwa akurasi tertinggi diperoleh dengan learning rate 0.01 dan pengurangan learning rate 0.1 .

Analisa pengaruh jumlah data latih bertujuan untuk membandingkan tingkat akurasi pengujian terhadap jumlah data latih dan data baru. Hasil pengujian terhadap jumlah data latih dapat dilihat pada Tabel 3.

TABEL 3. ANALisis JUMLAH Data LATIH

\begin{tabular}{|c|c|c|c|c|}
\hline \multirow{2}{*}{ No } & \multirow{2}{*}{ Jumlah Data Latih } & \multirow{2}{*}{ Jumlah Data Uji } & \multicolumn{2}{|c|}{ Tingkat Akurasi Pengujian (\%) } \\
\cline { 3 - 5 } & & & Data Latih & Data Uji \\
\hline 1 & 120 & 5 & 75 & 55 \\
\hline 2 & 360 & 15 & 62 & 57 \\
\hline
\end{tabular}

Hasil analisa pada Tabel 3 terjadi penurunan tingkat akurasi jika menggunakan 360 set data latih. Hal ini disebabkan perbedaan cara setiap orang dalam membayangkan suatu gerakan yang menyebabkan data latih menjadi tidak akurat. Namun terjadi peningkatan akurasi pada data uji.

Analisa pengaruh ekstraksi dapat dilihat pada Tabel 4.

TABEL 4. ANALISIS PENGARUh EKSTRAKSI

\begin{tabular}{|c|c|c|c|c|c|}
\hline \multirow{2}{*}{ No } & \multirow{2}{*}{$\begin{array}{c}\text { Jumlah Data } \\
\text { Latih }\end{array}$} & \multirow{2}{*}{ Jumlah Data Uji } & Skenario Percobaan & \multicolumn{2}{|c|}{$\begin{array}{c}\text { Tingkat Akurasi Pengujian } \\
\text { (\%) }\end{array}$} \\
\cline { 4 - 6 } & \multirow{2}{*}{1} & \multirow{2}{*}{5} & Ekstraksi & 75 & 55 \\
\hline 2 & & & Tanpa Ekstraksi & 70 & 48 \\
\hline
\end{tabular}

Hasil analisa pada Tabel 4 menunjukan bahwa ekstraksi Spektral Daya dapat meningkatkan akurasi data latih dan data uji dari $70 \%$ untuk data latih menjadi $75 \%$ dan $48 \%$ untuk data baru menjadi $55 \%$.

\section{KESIMPULAN}

Penelitian ini telah menghasilkan sebuah sistem identifikasi sinyal EEG saat membayangkan gerakan maju, berhenti dan melompat menggunakan ekstraksi Spektral Daya dan Learning Vector Quantization menggunakan empat kanal yaitu AF3, AF4, T7 dan T8. Hasil identifikasi divisualisasikan dalam sebuah video game sebagai aksi karakter untuk bergerak maju, berhenti dan melompat. 


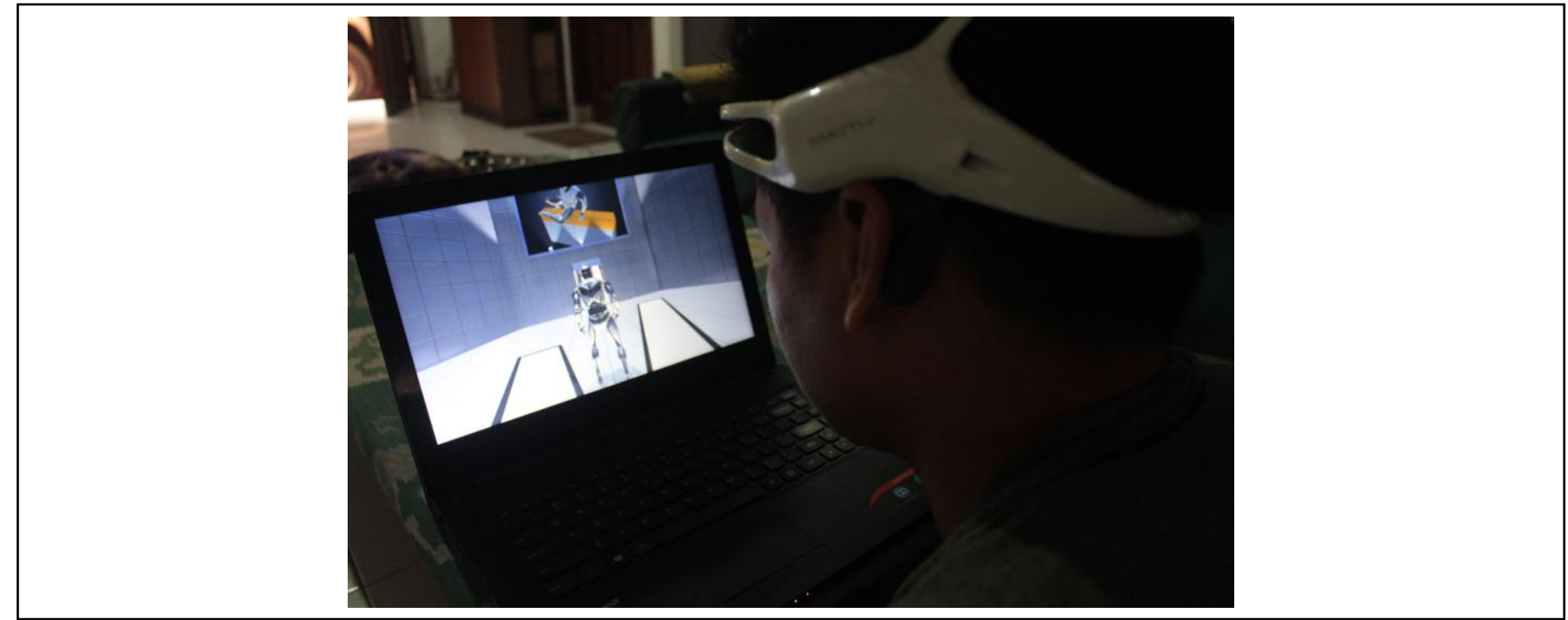

Gambar 12. Hasil Pengujian Identifikasi Real Time

Dari pengujian didapatkan hasil bahwa data latih dan data uji yang diekstraksi menggunakan Spektral Daya dapat meningkatkan tingkat akurasi saat identifikasi dari 70\% menjadi $75 \%$ untuk data latih dan $48 \%$ menjadi 55\% untuk data uji. Untuk parameter Learning Vector Quantization didapatkan parameter yang paling optimal yaitu dengan learning rate 0.01 dan pengurangan learning rate 0.1 dengan akurasi $75 \%$ untuk data latih dan $55 \%$ untuk data uji.

Selain itu juga, jumlah data yang digunakan berpengaruh dengan tingkat akurasi karena dengan 360 set data latih akurasi yang didapatkan hanya $62 \%$ untuk data latih dan $57 \%$ untuk data uji sedangkan dengan 120 set data latih akurasinya $75 \%$ untuk data latih dan 55\% untuk data uji. Hal ini disebabkan cara membayangkan gerakan yang berbeda-beda pada setiap orang. Sistem dapat mengenali data dari setiap naracoba dengan rata-rata sebesar $77 \%$ untuk data latih dan $67 \%$ untuk data uji. Dengan waktu identifikasi 0.075 detik untuk satu segmen.

\section{DAFTAR PUSTAKA}

[1] P. A. Pour, T. Gulrez, O. AlZoubi, G. Gargiulo and R. A. Calvo, "Brain-Computer Interface: Next Generation Thought Controlled Distributed Video Game Development Platform," in IEEE Symposium on Computational Intelligence and Games, 2008.

[2] A. Khong, L. Jiangnan, K. P., T. and A. P. Vinod, "BCI based Multi-player 3-D Game Control using EEG for Enhancing Attention and Memory," San Diego, 2014.

[3] L. Vokorokos, N. Adam and B. Mados, "Non-Invasive Brain Imaging Technique for Playing Chess with Brain-Computer Interface," International Journal of Computer and Information Technology, vol. 3, no. 5, pp. 877-882, 2014.

[4] E. C. Djamal and Suprijanto, "Recognition of Electroencephalogram Signal Pattern against Sound Stimulation using Spectral of Wavelet," in TENCON, 2011.

[5] M. Y. Abdullah, E. C. Djamal and F. Renaldi, "Aksi Game Arcade Berdasarkan Pikiran Menggunakan Filter Fast Fourier Transform dan Learning Vector Quantization," in Seminar Nasional Aplikasi Teknologi Informasi, Yogyakarta, 2016.

[6] A. Napoli, M. Barbe, K. Darvish and I. Obeid, "Assessing Traumatic Brain Injuries Using EEG Power Spectral Analysis and Instantaneous Phase," in 34th Annual International Conference of the IEEE EMBS, California, 2012.

[7] N.-H. Liu, C.-Y. Chiang and H.-C. Chu, "Recognizing the Degree of Human Attention Using EEG Signals from Mobile Sensors," in sensors, 2013.

[8] R. Ekayama, E. C. Djamal and A. Komarudin, "Identifikasi Kondisi Rileks Dari Sinyal EEG Menggunakan Wavelet dan Learning Vector Quantization," in Prosiding SNST, Semarang, 2016.

[9] L. Li, L. Xiao and L. Chen, "Differences of EEG between Eyes-Open and Eyes-Closed States Based on Autoregressive Method," Journal Of Electronic Science And Technology Of China, vol. 7, no. 2, pp. 175-179, 2009.

[10] G. Varghese, J. James, L. Joseph, M. K. John, S. Mathew and S. Ramachandhran, "Human Robot Cooperative System Based on Non-invasive Brain Computer Interface," National Conference on Recent Advances in Electrical \& Electronics Engineering, vol. 4, no. 1, pp. 118-123, 2015.

[11] T. Shanmugapriya and S. Senthilkumar, "Robotics and the Brain-Computer Interface System: Critical Review for Manufacturing Application," International Journal of Innovative Research in Computer and Communication Engineering, vol. 2, no. 2, pp. 2929-2935, 2014.

[12] E. C. Djamal, Suprijanto and S. J. Setiadi, "Classification of EEG-Based Hand Grasping Imagination Using 
Autoregressive and Neural Networks," Jurnal Teknologi, vol. 78, no. 6-6, pp. 105-110, 2016.

[13] Hindarto, "Identifikasi Sinyal EEG Menggunakan Koefisien Regresi Dan Jaringan Syaraf Tiruan," in Simposium Nasional Teknologi Terapan, 2013

[14] T. S, S. M. S, M. C, R. Saxena, T. R. Prasad and A. Tiwari, "Brain Computer Interface Systems to Assist Patients Using EEG Signals," International Journal of Innovative Research in Computer and Communication Engineering, vol. 3, no. 6, 2015.

[15] M. H. Alomari, A. AbuBaker, A. Turani, A. M. Baniyounes and A. Manasreh, "EEG Mouse: A Machine Learning-Based Brain Computer Interface," International Journal of Advanced Computer Science and Applications (IJACSA), vol. 5, 2014

[16] E. A. Mohamed, M. Z. B. Yusoff, N. K. Selman and A. S. Malik, "Enhancing EEG Signals in Brain Computer Interface Using Wavelet Transform," International Journal of Information and Electronics Engineering, vol. 4, 2014.

[17] T. J. Choi, J. O. Kim, S. M. Jin and G. Yoon, "Determination of the Concentrated State Using Multiple EEG Channels," International Journal of Computer, Electrical, Automation, Control and Information Engineering, vol. 8, no. 8, pp. 13731376, 2014.

[18] Y. Arifianto and N. Hidayat, "Penerapan Metode Power Spektrum pada Proses Konversi Suara Ucapan Menjadi Teks," Teknologi Informasi dan Telekomunikasi, 2013.

[19] M. D. Wuryandari and I. Afrianto, "Perbandingan Metode Jaringan Syaraf Tiruan Backpropagation Dan Learning Vector Quantization Pada Pengenalan Wajah," KOMPUTA, vol. 1, pp. 45-51, 2012. 